\title{
ENTREPRENEURIAL ORIENTATION, SYNERGY AND FIRM PERFORMANCE IN THE AGRIBUSINESS CONTEXT: AN EMERGING MARKET ECONOMY PERSPECTIVE
}

\section{Kruja (Demneri), A.}

Alba Kruja (Demneri) / Epoka University, Faculty of Economics and Administrative Sciences, Department of Business Administration, Rr. Tirane-Rinas, Km.12, Tirana, Albania. Email: akruja@epoka.edu.al.

\begin{abstract}
Entrepreneurship researchers have called for more investigation on the contribution of context in advancing entrepreneurship theory. The aim of the paper is to analyse the agribusiness enterprise performance by introducing collaborativeness as a dimension of entrepreneurial orientation. Agribusiness is a key regional sector representing a crucial ratio of employment, economic production. and future growth. Due to the sector's importance and the many challenges it faces, the impact of a synergy approach entrepreneurial orientation model on agribusiness performance is tested.

Structural equation modelling is used to test data collected from 120 agribusinesses located in Albania. Study results show collaborativeness as a dimension of the extracted entrepreneurial orientation model which provides a synergy between the actors of entrepreneurial value creation and has a significant direct contribution to enterprise performance.

Implications for Central European audience: Even though the results are related to agribusinesses in Albania, the findings of this research may advocate that to enhance enterprise performance in fragile sectors and emerging economy markets, the synergy among the value creation actors of the entrepreneurial process is a necessity. Besides the theoretical implications, this study has also some practical implications for policymakers, entrepreneurs and researchers.
\end{abstract}

Keywords: entrepreneurial orientation; synergy; performance; emerging market economy; agribusiness sector

JEL Classification: L26, L25, Q13

\section{Introduction}

The concept of entrepreneurship is a separate study area with a variety of features and applications. Most policymakers and academics agree that entrepreneurship is critical to the development and well-being of society (Kelley, Bosma, \& Amoros, 2011, p. 12). Nowadays entrepreneurship is perceived as a generator of economic expansion, employment generation, and societal development worldwide. Entrepreneurship activities increase product diversity of companies, creating new market opportunities, and generating new ways of competing with other market players, and all these contribute to the well-being of the 
company through enhancing success (Kantur, 2016, p. 29). As the field of strategic management developed, however, the emphasis shifted to entrepreneurial processes, that is, the methods, practices, and decision-making styles managers use to act entrepreneurially (Lumpkin \& Dess, 1996, p. 136). Rauch, Wiklund, Lumpkin, \& Frese (2009, p. 763) argue that "entrepreneurial orientation (EO) represents the policies and practices that provide a basis for entrepreneurial decisions and actions". As much of the published work investigates the reasons why some firms behave entrepreneurially, the consequences of doing so, the cultural and contextual factors that facilitate or inhibit corporate entrepreneurial behaviours, and whether the antecedents and moderating influences differ systematically from conservative firms (Gupta \& Gupta, 2015, p. 55). The methodological sophistication of these studies and the complexity of the models developed and tested have tended to grow considerably over time (Miller, 2011, p. 876).

Entrepreneurship scholars have attempted to explain performance by investigating a firm's EO (Wiklund \& Shepherd, 2003, p. 1308). Studies about the EO and its impact on business performance, started by the 1980s and has spread to many countries. Whereas there are many studies researching and proving the EO - performance relationship for developed countries (Gupta \& Gupta, 2015; Hughes \& Morgan, 2007; Lumpkin \& Dess, 1996; Wiklund, \& Shepherd, 2005), for the emerging economies this relationship commenced to be studied during this last decade (Cai, Liu, Deng, \& Cao, 2014; Chaston \& Scott, 2012; lqbal \& Malik, 2019; Kantur, 2016; Urban, 2012; Yiu \& Lau, 2008). The meta-analysis conducted by Rauch et al. (2009) on EO-performance relationship advocates further research of the topic in divergent contexts to put up whether the positive association will persist or not. De Massis, Kotlar, Wright, \& Kellermanns (2017, p. 4) emphasize "on the importance of context for understanding entrepreneurship determinants, behaviour and outcomes". Meanwhile, FitzKoch, Nordqvist, Carter \& Hunter (2017, p. 159) suggest that "agricultural sector context provides an opportunity for entrepreneurship scholars to better apply existing theory by anchoring their analysis in the context's entrepreneurial phenomena". Agribusiness is a very important sector, which represents a large share of employment, economic output and future growth potential of the region (EBRD, 2010). EO can enable a tool for the development of agribusiness by increasing revenues, increasing profits, developing products, services and new processes which can bring a competitive sustainable edge (Baran \& Velickaite, 2008). The conceptual arguments of previous research converge on the idea that firms benefit from highlighting newness, responsiveness, and a degree of boldness (Rauch et al., 2009, p. 764). In emerging economies, the available literature about innovation and entrepreneurship is limited to explore the determinants of innovation performance as well as innovation constrains (Guerrero \& Urbano, 2016, p. 294). Entrepreneurship scholars have called for more investigation on the contribution of context in advancing entrepreneurship theory and considering a specific sector in an emerging market is crucial for entrepreneurship research. Due to the sector's importance and the many challenges it faces by operating in an emerging economy, a triple helix actor synergy approach of EO is investigated. Through this study it is aimed to analyse the agribusiness enterprise performance by introducing collaborativeness as a dimension of EO construct. The research provides an appraisal and affirmation of the entrepreneurial model on a sample study of 120 agribusinesses in Albania. 


\section{Agribusiness sector in an emerging market}

Albania has experienced a major transformation over the last quarter of the century, emerging from a particularly isolated form of communism in the early 1990s, facing substantial challenges of forming a responsive democratic system of government and developing a modern economy (O`Brien, Nedelkoska, \& Frasheri, 2017, p. 3). While the market evolution is still going ahead, it is still restricted as an efficiency-driven economy (Schwab, 2018). Among 137 participating countries, it is listed 83rd by the report of Global Entrepreneurship Index, where its strongest area of entrepreneurship is pointed out to be people's entrepreneurial qualities (scoring 57 out of 100), while the weakest one is indicated to be the quality of the institutions that support entrepreneurship (with a score of 38) (Acs, Szerb, Autio, \& Lloyd, 2017). Albania needs to become more competitive through the production process and quality improvement, as well as investing in business sophistication and innovation to become an innovation-driven economy (Schwab, 2018).

Agri-food sector is among the most important economic sectors in Albania, contributing to about a fifth of the GDP and accounting for about half of the employment (Gecaj, Shahu, Imami, Skreli, \& Jambor, 2018, p. 3). Agricultural land constitutes $42.86 \%$ of the total land surface. The country`s geographic positioning, $1 / 3$ of which is wet by the Adriatic and lonian Seas, permits the cultivation of agricultural products in a fertile land of coastal areas as well as the concentration of the greatest share of vegetables producing and fruit trees raising. Albania`s northern part is suitable for growing chestnut while the alpine region is convenient for cultivating a lot of medicinal and aromatic plants.

The agribusiness sector in Albania is mainly run by family businesses, and apart from the favourable climate and positioning of the country, the sector is very fragile and critical, relying on the quality of operations arranged in its system. A natural system dependent on the agricultural cycle of plants and animals, and interdependent among enterprises in its supply chain, operating in a risky and uncertain environment.

As a sector characterized by a strong regulatory framework, agriculture provides an important setting to explore how different regulative, normative and cognitive aspects interact and influence entrepreneurship (Fitz-Koch et al., 2017, p. 156). In most Western Balkans (WB), agriculture has played a buffer role in a generally deteriorating economic situation and continues to play an important role in maintaining a social equilibrium (Volk, 2010, p. 2). Even though the critical role in-country development of the sector, as reported by European Union (EU) report on agricultural policy developments in WB for 2019, the proportion of market and direct producer support measures in Albania is very low. Reporting on budgetary support for agriculture tends to be insufficiently transparent, while policy impact assessments and evaluations are practically non-existent, resulting in low quality in policy planning and noninclusive decision-making (Ciaian, 2019, p. 8). These subsidies provided to producers of developed economies, but not properly in Albania, makes the country`s sector less competitive in the domestic as well as in the international market. The same concern is pointed by World Bank (2007), which reports that the granted sector subsidies in developed economies have provided years of underinvestment to the emerging markets agribusiness sector. Preconditions for the development of agro-industries are the necessary transportation, information and communication technologies (ICT) and access to reliable supplies of key utilities, notably electricity and water (Henson \& Cranfield, 2009, p. 35). Moreover, agriculture-specific infrastructure such as laboratories for product testing and 
certification purposes is a must if the sector is to be competitive, particularly in compliance with the sanitary and phytosanitary standards for world food trade (Mhlanga, 2010, p. 24). Albania faces a unique knowhow constraint that is deeply rooted in its closed-off past, and the limited diversification that has taken place in the private sector can, in nearly all cases, be linked to distinct inflows of knowhow (O`Brien et al., 2017, p. 3). In turn, the infrastructural constraints under which the agro-industrial sector operates influence the cost and reliability of the physical movement of raw materials and end products, efficiency of processing operations, responsiveness to customer demands, etc. (Henson \& Cranfield, 2009, p. 35).

Entrepreneurship research in Albania has begun by the early years of the 21st century, a decade after the entrepreneurial process itself started in this post-communist country. Being an emerging country in transition, the researchers have targeted analysing the obstacles and barriers faced by enterprises, especially small to medium ones (Asllani, Becherer, \& Theodhori, 2014; Bitzenis \& Nito, 2005; El Alaoui, Shopovski, Kvirkvaia, Alam, \& Ofili, 2016; Kruja, 2013a; Rinkel, Cormier, Zheng, \& Saikat, 2016; Xheneti \& Smallbone, 2008). The focus of entrepreneurship researchers for Albania has also been university students entrepreneurial intention during the second decade of the 21st century (Kruja, 2019; Kume, Kume, \& Shahini, 2013; Zenelaj \& Kruja, 2017). All these studies point out the hostile environment of this transition economy which is striving for 30 years to build an entrepreneurial competitive market. The creation of an entrepreneurial economy can foster economic development, systematically fight corruption, and allow Albania to economically join the rest of Europe (Asllani et al., 2014, p. 243). Among the recommendations provided by Rinkel et al. (2016) in their entrepreneurial ecosystem analysis of the Albanian market, suggest different types of collaborations to overcome the obstacles to develop entrepreneurship: the collaboration with similar organizations; collaboration between organizations and academia; collaboration between private and public sector. Consistent with these findings are also the results provided by the Kruja (2019) study on the entrepreneurial intention of university students in Tirana. Collaboration opportunities of students with industry, governmental and research institutions in supporting and building their innovative business ideas would positively affect their intention towards entrepreneurship.

Research on entrepreneurial orientation as well as on agribusiness sector entrepreneurship are vacant in this emerging economy, so the current study is not only coming through to bridge the gap in literature review but also to provide sectoral observations to triple helix actors, policymakers, entrepreneurs, and researchers.

\section{Entrepreneurial orientation and synergy}

Entrepreneurship research has grown tremendously over the last three decades, and the field`s focus has changed substantially over time (De Massis et al., 2017, p. 4). Since the publication of Shane and Venkataraman's (2000) article "The promise of entrepreneurship as a field of research" in the Academy of Management Review, entrepreneurship scholars have moved toward a process-based definition of entrepreneurship (Fayolle, 2013, p. ix). They defined entrepreneurship as the "scholarly examination of how, by whom, and with what effects opportunities to create future goods and services are discovered, evaluated, and exploited" (Shane \& Venkataraman, 2000, p. 218). This definition denotes a wide variety of entrepreneurial operations, including production innovation, start-ups, new ventures, corporate venture spinouts and spin-ins; and, more importantly, multiple levels of analysis 
from founder-focused, individual and dyadic levels up to field and international environment contexts (Jennings et al., 2013, p. 3).

Identifying the components advancing entrepreneurship will be the researchers' focus on the second half of the 20th century and following the 1980s the recognition of EO dimensions will occur. Miller \& Friesen (1982, p. 5) set the EO to cover firms that "innovate boldly and regularly while taking considerable risks in their product- market strategies". The entrepreneurial firm was defined by Miller (1983, p. 771) as the one which "engages in product market innovation, undertakes somewhat risky ventures, and is first to come up with 'proactive' innovations". This definition was supported also by Covin \& Slevin (1988), determining a firm`s EO as the aggregate of the intensity by which top managers approach taking risks, support novelty as a competitive advantage strategy and are competitive in the market. Therefore, firms which continuously take risks, innovate and approach proactive behaviour are oriented entrepreneurially, while the others presenting a low level of these actions are conservative-oriented. Many researchers have used these three dimensions (innovativeness, risk-taking, proactiveness) to measure firms EO (Covin \& Slevin, 1989; Wiklund \& Shepherd, 2005), meanwhile, Lumpkin \& Dess (1996) put on two other dimensions to this construct: autonomy and competitive aggressiveness.

As EO research has continued spreading, so have the variants for measuring the construct (Rauch et al., 2009, p. 767). Various arguments exist among researchers about the extent to which EO dimensions should be presented to a firm so that it is considered entrepreneurial. Debates related to the EO construct are numerous and unfortunately consensus regarding issues such as the appropriate design definition and its dimensionality has not yet been reached (Covin \& Lumpkin, 2011). According to Miller (1983), only firms that represent all EO dimensions (innovativeness, proactiveness, risk-taking) to the same extent can be considered entrepreneurs. Hughes \& Morgan (2007) emphasised that pro-activity is a critical factor in the embryonic growth phase as it provides the firm with market positioning, and less important as the firm is stabilized. Meanwhile, Lumpkin \& Dess (1996) showed that businesses engaging in a constructive integration of EO dimensions can be appraised as entrepreneurial. Scholars like Knight (1997), Thomas \& Mueller (2000) have argued that EO construct or specific dimensions may vary through countries.

In the entrepreneurship literature, innovativeness is the most important dimension of EO. It is considered a key factor for competitiveness and economic growth in a country. Lumpkin \& Dess (1996) emphasized the importance of innovation in entrepreneurship by proposing it as the only dimension to be applied by all entrepreneurial firms.

While risk-taking is the first quality attributed to entrepreneurs by Cantillon in 1755, the concept of innovation and its application to ventures has begun with Schumpeter in 1911. Schumpeter (1911/34) saw innovation to lead to up to date production function, such as presenting new goods; new manufacturing techniques; accessing new markets; acquisition of new raw material sources; or carry through a new firm. On the other side according to Drucker (1985, p. 32) "innovation is the specific tool to exploit changes as an opportunity for a different business or service". Montensen \& Bloch (2005, p. 46) defined innovation as "the implementation of a new or significantly improved product (good or service), or process, a new marketing method, or a new organizational method in business practices, workplace organization or external relations". Lewrick, Omar, Raeside, \& Sailer (2010, p. 1) explained innovation as "the production, diffusion, and use of new and economically useful knowledge, 
a key factor for competitiveness and growth while entrepreneurship the process of business start-up, business creation and growth, the entrepreneurial dynamism is key to economic renewal and growth". However, this need for continuous innovations drives the system(s) into becoming knowledge-based (Leydesdorff \& Meyer, 2006, p. 1447). Knowledge is the key element of the innovation systems and the institutions which have an important role in its development can be stated as: universities and academic institutions (develop and transfer knowledge); government organizations; innovative enterprises (Kruja, 2013b, p. 7). The "triple helix" is a spiral model of innovation that captures multiple reciprocal relationships at different points in the process of knowledge capitalization (Etzkowitz, 2002, p. 2), defined as a "laboratory for knowledge-based economic development" (Etkowitz \& Leydersdorff, 1995). The triple helix denotes the university-industry-government relationship as one of relatively equal, yet interdependent, institutional spheres which overlap and take the role of the other (Etzkowitz, 2002, p. 2). In the triple helix model constructed advantages have been conceptualized as the surplus-value of an overlay of relations among the three components of a knowledge-based economy: (1) the knowledge-producing sector (science), (2) the market, and (3) governments (Cooke \& Leydesdorff, 2006, p. 7). To generate synergy it is required "a platform for participation through the development of dialogues, between disciplines and people, the very stuff of systems thinking" (Castell, Gregory, Hindle, James, \& Ragsdell, 1999, p. v). As synergy is systemic, it should be contextualised in the process perspective (Benecke, Schurink, \& Roodt, 2007). Systemness can be operationalized and measured in terms of the generation of new options (Leydesdorff, Etzkowitz, Ivanova, \& Meyer, 2017). It is important to note that the probability of developing interrelationships for synergy is not merely a matter of paper and pencil calculations but is heavily dependent on implementation concerns (Ensign, 1998, p. 666). Without such operationalization, the notion of system tends to lead to reification; knowledge-based systems are not given but constructed (Leydesdorff et al., 2017). For research knowledge, industry and government can be expected to pay more for privileged access to knowledge-based growth opportunities by funding research, stimulating closer interactions among the three institutional partners, subsidizing infrastructure (e.g., incubators and science parks), and stimulating academic entrepreneurship skills and funding (Cooke \& Leydesdorff, 2006, p. 8). Montensen \& Bloch (2005) grouped the components guiding enterprise innovation activities as: (i) institutional and infrastructural environment; (ii) innovation policy through different supports and incentives; (iii) education system and R\&D activity of the government (e.g. the activities of the universities); (iv) innovation activity of other companies; (v) the interaction of the above in relation to demand. Studies in emerging economies provide empirical insights into the obstacles to innovation and the majority of them have an emphasis on the financial constraints that affect innovation in SMEs (Guerrero \& Urbano, 2016, p. 297). In the same line with previous researchers, Rinkel et al. (2016) to overcome these obstacles and to support the entrepreneurial process in Albanian, suggest (i) collaboration with similar organizations; (ii) collaboration between organizations and academia; (iii) collaboration between private and public sector. Collaboration is seen as a key to the development of the innovative processes, reducing the risk that entrepreneurs constantly face, and foremost for sustainable development of the economy. Increased collaboration between government institutions - research institutions and the sector are expected to increase opportunities and facilitate entrepreneurs in implementing innovations, taking risk and enhancing their performance. 
Balderbos, Carree, \& Lokshin (2004) researched the role of different types of R\&D cooperation on enterprise performance. They found that $R \& D$ cooperation with competitors and suppliers focusing on incremental innovations boosts enterprise productivity performance while university and competitor cooperation aiming the release of new innovative products, boosts firm growth.

Guerrero \& Urbano (2016) analysed the effect of triple helix agents on the performance of entrepreneurial innovations on Mexican firms. Their study was focused especially on researching the innovation performance effect generated by the association of enterprises with each other as well as with universities and government.

In the management literature, synergy has generally been used to mean an overall fit or congruence between units (Ensign, 1998, p. 658). Other researchers have studied the shared consequences among actions instead of the whole operational units. Ensign (1998), studied the joint effects of activities in the value chain. In this research, the joint effects of governmentindustry-research institutions collaboration as an EO dimension on performance will be studied. Consequently, it is hypothesised that:

H1: Risk-taking, innovativeness, proactiveness, autonomy, competitive aggressiveness, and collaborativeness are dimensions of EO construct of agribusinesses in Albania.

H2: EO construct is unidimensional.

The scale developed by Covin \& Slevin (1989) is used to measure innovativeness, risktaking and proactiveness dimensions of EO construct and the scale of Lumpkin \& Dess (1996) is used for autonomy and competitive aggressiveness. To measure collaborativeness is used the extent of enterprises different types of collaborations, such as with: (i) research institutions, (ii) governmental institutions, (iii) business associations, (iv) domestic businesses, (v) foreign businesses and (vi) innovation NGOs.

\section{EO - performance relationship}

The EO-performance relationship is one of the most important topics that has attracted the attention of many researchers. Conceptually, there is a strong consensus among researchers regarding the fact that the result of entrepreneurial activities is performance improvement. Researchers have claimed that activities that present a high level of EO lead to higher enterprise performance (Pearce \& Carland, 1996; Zahra, 1991; Zahra \& Covin, 1995; Wiklund, 1999; Wiklund \& Shepherd, 2005). Most studies have shown that those enterprises that adopt EO to a large extent perform much better than other ones that do not (Covin \& Slevin, 1986; Hult, Snow, \& Kandemir, 2003; Keh, Nguyen, \& Ng, 2007; Li, Huang, \& Tsai, 2009; Wiklund \& Shepherd, 2003). Other studies have reported a lower correlation between EO and performance (Lumpkin \& Dess, 2001; Zahra, 1991). While there are other scholars who have not been able to find a positive relationship between EO and performance (Covin, Slevin, Schultz, 1994; George, Wood, \& Khan, 2001; Slater \& Narver, 2000). On the other site Rauch et al. (2009) point out that the effect of EO on performance is possibly dependent on moderating variables such as industry type, business size, and international contexts. Therefore, the current study investigates whether the derived EO construct in the agribusiness sector context of a post-communist country positively affects business performance. Consequently, it is hypothesised that: 
H3: There is a positive relationship between the EO construct and the performance of agribusinesses.

\section{Methods}

The structured questionnaire technique was used for collecting primary data. Data collection was carried out by disseminating questionnaires to agribusiness sector managers/entrepreneurs operating in different cities of Albania. The sample of 170 agribusinesses was set up from the agribusiness list provided by the Albanian Agrobusiness Council, the union of agribusiness associations in the country by using systematic random techniques to ensure participation from the northern, central and southern zones of Albania. The completion of the questionnaires was mostly carried out through direct contacts, visiting them in their enterprises by the researcher during the period June-September 2014. Another part of the surveys was conducted during their participation in the Agribusiness 2014 Fair in Str. "Murat Toptani", Tirana between 25-28 September 2014. A small number of entrepreneurs were contacted by email, after a telephone conversation explaining the purpose of the study. From a total of 170 distributed questionnaires, 120 usable ones were completed and collected back from the agribusinesses, with a $70 \%$ response rate.

Sample characteristics are provided in Tab. 1 below. The majority of respondents (44\%) are located in the central region of Albania, while 31\% from the northern part and $25 \%$ from the southern area. Most of the participating enterprises are micro to small ones, as well as family businesses, which is mainly a characteristic of the agribusiness sector. Their average age of market experience is about 13, part of them are newly established, while others operate since the establishment of an open market in Albania.

Table 1 | Sample characteristics

\begin{tabular}{lccccc}
\hline Region of Albania & Northern & $31 \%$ & Agribusiness age & $1-5$ & $22.5 \%$ \\
& Central & $44 \%$ & $6-10$ & $16.6 \%$ \\
& Southern & $25 \%$ & $11-15$ & $21.6 \%$ \\
Employee number & $1-9$ & $32 \%$ & $16-20$ & $24.2 \%$ \\
& $10-19$ & $38 \%$ & $>21$ & $15 \%$ \\
& $>20$ & $30 \%$ & & \\
\hline
\end{tabular}

Source: author

Referring to the "Expert Panel" method, the content of the questionnaire used was examined by three experts in Albania. Two agribusiness and one management expert were consulted on the validity of the questionnaire internal construct for the case of Albania and the agribusiness sector. Based on the experts' assessments, the reformulation and reconstruction of the questionnaire was made.

To ensure the credibility of the questionnaire, a preliminary test was also conducted with respect to the sample of surveyed enterprises. Cronbach alfa levels were measured for the EO dimensions as well as performance and were found to be acceptable by showing their consistency and reliability.

The questionnaire was structured in three sections. Section one included questions related to the collection of general information about the agribusiness. In section two data related to the agribusiness entrepreneurial orientation (independent variable), and in the last section data measuring the agribusiness performance (dependent variable) were collected. 


\section{Measures}

\subsection{Entrepreneurial orientation}

Innovativeness, risk-taking and proactiveness were measured by using the scale developed by Covin \& Slevin (1989), autonomy and competitive aggressiveness were measured by using the scale of Lumpkin \& Dess (1996). Collaborativeness is a new dimension, to be tested together with the previous five ones in a sample of agribusiness sector firms in a developing country like Albania. Based on the triple helix model, collaborativeness focuses on the different forms of collaboration between research institutions, government institutions, and the industry itself. Six statements are used to measure the collaborations of the agribusinesses with research institutions, governmental institutions, business associations, domestic businesses, foreign businesses and innovation NGOs, to construct knowledgebased systems of competitive advantage. Detailed information about the statements of the scale of the questionnaire for EO and items coding is provided in the appendix of the study (Tab. 1A).

A 5-points Likert scale was used to measure the statements, evaluated accordingly: $1=$ strongly disagree; 2 = disagree; $3=$ neutral; $4=$ agree; and $5=$ strongly agree. Only for the dimension of autonomy, the statements were evaluated in the reverse order.

\subsection{Performance}

Firm performance was measured by using the weighted average performance index of 5 criteria developed by Gupta \& Govindarajan (1984) and used also by Covin \& Slevin (1989). The selected criteria are: (1) firm 's profits, (2) return on investment, (3) increase in sales, (4) profit-sales ratio, and (5) market share. The respondents evaluated by using a five-point Likert scale from 1 to 5 their satisfaction as well as the importance of each of these criteria. These "satisfaction" scores were multiplied by the "importance" scores in order to compute a weighted average performance index for each firm (Covin \& Slevin, 1989). Such a multivariate approach with criterion weights was seen as particularly appropriate in a context in which, by definition, different strategic missions imply quite different sets of priorities (Gupta \& Govindarajan, 1984, p. 34).

\section{Analysis and results}

The purpose of measurement in theory testing and development research is to provide an empirical estimate of each theoretical construct of interest (Gerbing \& Anderson, 1988, p. 186). In this research, the constructed model of EO was examined for Albanian agribusinesses using EFA and CFA statistical analyses and was determined the performance model of agribusinesses (assessed the role of the EO and its dimensions on the performance of agribusinesses) using the structural equation modelling analysis.

Quantitative analysis applied in this research are Exploratory Factor Analysis (EFA), Confirmatory Factor Analysis (CFA) and Structural Equation Modelling (SEM), which were carried out on a sample of data collected through 120 questionnaires with the help of the IBM SPSS 20 and IBM SPSS Amos 20 statistical programs.

Exploratory factor analysis (EFA) with principal component extraction and varimax rotation method was applied to the randomly selected sample $(n=120)$. All the items related to the autonomy were excluded from the model as they caused multicollinearity. EFA analysis 
resulted in an EO model composed of 16 items from the tested 20 ones which were loaded on only three factors (with Eigenvalues greater than one). The extracted three factors from EFA analysis (Tab. 2) were Collaborativeness (loaded items are: C1, C2, C3, C4, C5, C6), Innovativeness (loaded items are: I1, I2, 13, P1, P2, CA) and Risk taking (R1, R2, R3, P3). Each of the factors had coefficient $\alpha \geq 0.85$ and $\mathrm{KMO}=0.88$, achieving the reliability as recommended by Nunnally (1978).

Table 2 | Summary of EFA analysis

\begin{tabular}{lccc}
\hline & \multicolumn{2}{c}{ Rotated Factor Loadings } & \\
Items & Collaborativeness & Innovativeness & Risk-taking \\
\hline C3: agribusiness associations & 0.88 & & \\
C1: research institutions & 0.85 & & \\
C2: governmental institutions & 0.82 & \\
C6: innovation NGOs & 0.73 & \\
C4: domestic businesses & 0.64 & & \\
C5: foreign businesses & 0.56 & & \\
I2: new product lines & & 0.90 & \\
I3: changes in products & & 0.85 & \\
I1: R\&D leadership & & 0.69 & \\
P2: new techniques & & 0.48 & \\
P1: competitive initiatives & & 0.48 & \\
CA1: competitive & & 0.44 & \\
R2: wide ranging acts & & & -0.89 \\
R1: high-risk proclivity & & & -0.90 \\
P3: competitive posture & & & -0.74 \\
R3: opportunity exploitation & 7.2 & 1.9 & -0.67 \\
Eigen values & 45 & 11.2 & 8.7 \\
Variance \% & 0.87 & 0.85 & 0.86 \\
a & & 0.88 & \\
KMO & & & \\
\hline
\end{tabular}

Source: author

To determine whether the theoretical specifications of this extracted construct match the sample data of this study, Confirmatory Factor Analysis (CFA) using the maximum likelihood method in AMOS 20 was applied. As Anderson \& Gerbing (1988) recommend, were evaluated the unidimensionality, convergent validity and discriminant validity for the measurement model. Hattie (1985) emphasizes the most critical and basic assumption of the unidimensionality measurement theory that a set of items forming an instrument that measures just one thing in common. An item is considered unidimensional if the systematic differences within the item variance are only due to one variance source, that is, one latent variable (Ziegler \& Hagemann, 2015, p. 231). Since the initial analysis resulted in an unacceptable fit of the extracted model, the EO model was reidentified by analysing the diagnostic indicators. To obtain the model fit, 3 items were removed from the model (CA, P1 and P2). After the modifications, the goodness of fit (GOF) indices showed that the derived model fits into the set of observations (Tab. 3). 
Table 3 | GOF indices of the EO model

\begin{tabular}{lccc}
\hline Fit indices & Model value & Cut-off value & Fit status \\
\hline $\mathbf{X}^{2}$ (df) & $78.987(60)$ & $p>0.05$ & Fit \\
$\mathbf{p}$ & 0.051 & $($ at $\alpha=0.05)$ & \\
RMSEA & 0.049 & $\leq 0.05$ good & Fit \\
$\left.\mathbf{~} \mathbf{X}^{2} / \mathbf{d f}\right)$ & 1.316 & $\leq 2.0$ very good & Fit \\
TLI & 0.952 & $\geq 0.90$ & Fit \\
CFI & 0.968 & $\geq 0.90$ & Fit \\
\hline
\end{tabular}

Source: author

The extracted EO model construct validity was tested through convergent and discriminant validity analysis. All item loadings were statistically significant at $95 \%(\alpha=0.05), C R>1.96$ and standardized regression weights are greater than 0.664 , proving the convergence validity. This showed that the set of measured elements currently reflects the theoretical (latent) construct for which these elements were designed to measure. Discriminant validity was measured by comparing between constructs of the average variance extracted variable (AVE) with the square intercorrelation. AVE values for each construct resulted greater than the square intercorrelation values between each construct and all other constructs, thus verifying the discriminatory validity of the EO model.

As the EO construct was validated, the structural model of measuring the EO - performance relationship was investigated. The magnitude and the direction of the standardized regression weights of parameter estimates were positive and greater than 0.5 , but not all of them were significant (at $p$-value $>0.05$ and $C R<1.96$ ) to performance. At the same time, the GOF indices resulted in an unacceptable fit of the structural model. The analysis of modification indices and standardized residual covariance resulted in structural model problems associated with the item P3. After its removal, the structural model was retested. This time the magnitude and the direction of the standardized regression weights of parameter estimates were positive, greater than 0.5 , but the value of $p<0.05$ and $C R$ values $>$ 1.96 did not match for the innovativeness items where $p=0.575>0.05$ and $C R=0.561<1.96$, indicating that there is a positive relationship between the innovativeness dimension and the performance which is not significant (Tab. 4). On the other side, the GOF indices results showed that the derived structural model fits into the set of observations (Tab. 5).

Table 4 | Structural model standardised regression weights and CR values

\begin{tabular}{|c|c|c|c|c|}
\hline & Estimate & $\begin{array}{l}\text { Standard } \\
\text { Error }\end{array}$ & $\begin{array}{l}\text { Critical } \\
\text { Ratio }\end{array}$ & Probability \\
\hline C5 <--- Collaborativeness & 1.000 & & & \\
\hline C4 <--- Collaborativeness & .844 & .137 & 6.167 & *** \\
\hline C6 <--- Collaborativeness & 1.003 & .166 & 6.026 & *** \\
\hline C2 <--- Collaborativeness & 1.057 & .167 & 6.346 & *** \\
\hline C1 <--- Collaborativeness & 1.154 & .174 & 6.624 & *** \\
\hline C3 <-- Collaborativeness & 1.385 & .191 & 7.256 & *** \\
\hline I1 <--- Innovativeness & 1.000 & & & \\
\hline 13<--- Innovativeness & 1.129 & .166 & 6.784 & *** \\
\hline $12<--$ Innovativeness & 1.071 & .161 & 6.644 & *** \\
\hline R3 <--- Risk-taking & 1.000 & & & \\
\hline R1 <--- Risk-taking & 1.323 & .165 & 8.014 & *** \\
\hline R2 <--- Risk-taking & 1.424 & .169 & 8.443 & *** \\
\hline Performance <--- Innovativeness & .331 & .590 & .561 & .575 \\
\hline Performance <--- Risk-taking & 1.502 & .737 & 2.037 & .042 \\
\hline Performance <--- Collaborativeness & 1.375 & .574 & 2.395 & .017 \\
\hline
\end{tabular}

Source: author 
Table 5 | GOF indices of the EO-performance structural model

\begin{tabular}{lccc}
\hline Fit indices & Model value & Cut-off value & Fit status \\
\hline $\mathbf{X}^{\mathbf{2}}$ (df) & $80.378(59)$ & $\mathrm{p}>0.05$ & Fit \\
$\mathbf{p}$ & 0.052 & $($ at $\alpha=0.05)$ & \\
RMSEA & 0.052 & $\leq 0.05$ good & Fit \\
( $\left.\mathbf{X}^{2} / \mathbf{d f}\right)$ & 1.362 & $\leq 2.0$ very good & Fit \\
TLI & 0.944 & $\geq 0.90$ & Fit \\
CFI & 0.963 & $\geq 0.90$ & Fit \\
\hline
\end{tabular}

Source: author

Achieving the unidimensionality of the structural model is indicative of a single construct of the extracted EO model and the interaction between them has a significant positive relationship with performance. These test results fully supported hypothesis 2 and 3 of the study, while hypothesis 1 was partially supported (risk-taking, innovativeness and collaborativeness resulted to be dimensions of the EO construct for the case of agribusinesses in Albania).

\section{Discussions}

This research focused on advancing the EO literature and its construct understanding through approaching the triple helix actors' synergy system aiming to boost agribusiness sector performance of an emerging economy.

Structural equation modelling was used to test the data collected from 120 agribusinesses located in Albania. EFA, CFA and SEM analysis results of this study, confirmed the unidimensionality of the EO and EO-performance models as well as the existence of a positive relationship between them, as suggested by Covin \& Slevin (1986). The study results are consistent with the literature of entrepreneurship (Cantillon, 1755; Schumpeter, 1911/34) and EO, where risk-taking and innovativeness are argued to be the most important dimension of EO. Also, as suggested by Hughes \& Morgan (2007), pro-activity did not result to be critical for the established agribusinesses, and it was excluded from the EO-performance construct. Another EO factor excluded from this study is autonomy, a dimension included in few EO studies (Lumpkin \& Dess, 1996), showing that autonomy does not always positively contribute to business performance and in some cases, the exercise of autonomy by employees or working groups can hurt the achievement of the firm's objectives. While, instead of competitive aggressiveness, this study suggests as a main factor to foster innovations and performance in the agribusiness sector collaborativeness. Research findings show collaborativeness as a dimension of the extracted EO model aiming to provide a synergy between the entrepreneurial value creation actors. This dimension has a significant direct contribution to enterprise performance. The fact that there is not a direct significant positive relationship between agribusiness innovativeness and performance shows that innovations applied without collaboration and risk-taking will not have a significant positive impact on performance. The reason behind this result is that the benefits of agribusinesses from innovation are not immediate and in the short run are low. Investments in innovation are long-term investments that contain numerous uncertainties and risks. This shows a direct and inevitable link between innovativeness and risk-taking factors. For this reason, the necessity of various collaborations with both governmental institutions, research institutions and the sector, in the agribusinesses context of an emerging economy is a must to increase the opportunities for better performance in the sector. Knowledge development is a key component of innovation and therefore importance is given to its development and transfer 
models. Interaction between government institutions - research institutions - and industry, is a necessity in the implementation of innovations toward sustainable development as the synergy provided with these collaborations would minimize the risk associated by the institutional instability and boost entrepreneurship.

\section{Conclusions and implications}

Entrepreneurship researchers have called for more investigation on the contribution of context in advancing entrepreneurship theory. The current research aimed to extend the EO literature by focusing on an emerging market of a transition economy, identified with its adverse and unstable operating environment. The study provided a new approach of performance enhancement in the agribusiness sector by introducing collaborativeness as a new dimension of a synergic EO model. The study presented an appraisal and affirmation of the EO construct on a sample study of 120 agribusinesses in Albania. Albania is a developing country, which has 28-years (1990-2018) experience of democracy and a free market. Agribusiness is a very important sector of this economy, employing more than half of the workforce and contributes around to fifth of the GDP. Because of the low profits of the sector, the number of employees is decreasing each year.

This research presented the agribusiness context, a fragile sector, operating in the hostile environment of a developing country. Based on the triple helix model, collaborativeness focused on the different forms of collaboration between research institutions, government institutions, and the industry itself. These synergic collaborations are key to the development of the innovation process, to reducing the risk that businesses continuously face, and foremost for a sustainable development of the economy. According to the research results, the obtained synergic EO model is expected to further sustain and stimulate entrepreneurship through agribusinesses' performance enhancement.

The study brings distinct contributions that have critical theoretical implications. First, entrepreneurship researchers have asked for increased investigation on the role of context in advancing entrepreneurship theory. Considering the agribusiness sector in an emerging market economy is crucial for entrepreneurship research, so this study has a deep contribution to the course of entrepreneurship research contextualization, as well as to the EO-performance relationship literature. Second, the study acknowledges that collaboration is a dimension of synergic EO. For this fragile sector of an emerging economy, it is rough to be entrepreneurially oriented, be a risk-taker and innovator, without the presence of the continuous collaboration mechanisms. Third, it was revealed that entrepreneurial behaviour is set apart from the "undo-the-competitors" posture by competitiveness achieved through different types of collaborations. Lastly, these study results invite entrepreneurship scholars to further exploit the impact of academia-industry-government collaborations on the entrepreneurship process and entrepreneurial performance for other emerging economies as well as developed ones and other sector contexts.

Besides the theoretical implications, this study has also some practical implications for policymakers and agribusiness entrepreneurs. The research results feature the urgency in advancing the policy-making conditions, building a convenient external environment for this fragile sector to properly grow and develop an appropriate innovation policy. Study findings suggest that innovative practices undertaken by agribusinesses would not boost their 
performance unless they are associated with collaborative initiatives within the triple helix synergy environment.

The study finding provides an improved perception of EO-performance relationship in the context of an emerging market, agribusiness sector, of a transition economy. Thus, policymakers, agribusiness entrepreneurs, researchers, not only in Albania but also in other developing economies or emerging markets, can take consideration of the study results in their decision making. Moreover, this study is a pioneer in examining synergy and EO role on the performance of the agribusiness sector in emerging economies. The findings of this study can be useful to other emerging countries in need to triple helix actors support not only the agribusiness sector but also other fragile sectors important to country development which provide a competitive advantage.

\section{References}

Acs, Z. J., Szerb, L., Autio, E., \& Lloyd, A. (2017). Global Entrepreneurship Index 2018. The Global Entrepreneurship and Development Institute. https://thegedi.org/wpcontent/uploads/dlm_uploads/2017/11/GEI-2018-1.pdf

Anderson, J. C., \& Gerbing, D. W. (1988). Structural equation modelling in practice: A review and recommended two-step approach. Psychological bulletin, 103(3), 411-423. http://citeseerx.ist.psu.edu/viewdoc/download?doi=10.1.1.540.4887\&rep=rep1\&type=pdf

Asllani, A., Becherer, R., \& Theodhori, Q. (2014). Developing a sustainable economy through entrepreneurship: The case of Albania. South-Eastern Europe Journal of Economics, 12(2), 243-262. http://www.asecu.gr/Seeje/issue23/issue23-asslani-becherer-theodhori.pdf

Balderbos, R., Carree, M., \& Lokshin, B. (2004). Cooperative R\&D and firm performance. Research policy, 33(10), 1477-1492. http://citeseerx.ist.psu.edu/viewdoc/download?doi=10.1.1.470.9960\&rep=rep1\&type=pdf

Baran, D., \& Velickaite, R. (2008). Building the theoretical framework of entrepreneurship. 5th International Scientific Conference (pp. 16-17). Vilnius: Business and Management.

Benecke, G., Schurink, W., \& Roodt, G. (2007). Towards a substantive theory of synergy. SA Journal of Human Resource Management, 5(2), 9-19. https://doi.org/10.4102/sajhrm.v5i2.115

Bitzenis, A., \& Nito, E. (2005). Obstacles to entrepreneurship in a transition business environment: the case of Albania. Journal of Small Business and Enterprise Development, 12(4), 564-578. https://doi.org/10.1108/14626000510628234

Burns, T., \& Stalker, G. M. (1961). The management of innovation. Tavistock. https://www.jstor.org/stable/2230196

Cai, L., Liu, Q., Deng, S., \& Cao, D. (2014). Entrepreneurial orientation and external technology acquisition: an empirical test on performance of technology-based new ventures. Journal of Business Economics and Management, 15(3), 544-561. https://doi.org/10.3846/16111699.2013.770786

Cantillon, R. (1755). Essai sur la nature du commerce en general. https://www.libertyfund.org/books/essay-on-the-nature-of-trade-in-general

Castell, A. M., Gregory, A. J., Hindle, G. A., James, M. E., \& Ragsdell, G. (Eds.). (1999). Synergy matters: Working with systems in the 21st century. Springer Science \& Business Media. https://www.springer.com/gp/book/9781475771824 
Chaston, I., \& Scott, G. J. (2012). Entrepreneurship and open innovation in an emerging economy. Management Decision, 50(7), 1161-1177. https://doi.org/10.1108/00251741211246941

Cooke, P., \& Leydesdorff, L. (2006). Regional development in the knowledge-based economy: The construction of advantage. The Journal of Technology Transfer, 31, 5-15. https://doi.org/10.1007/s10961-005-5009-3

Covin, J. G., \& Lumpkin, G. T. (2011). Entrepreneurial orientation theory and research: Reflections on a needed construct. Entrepreneurship Theory and Practice, 35(5), 855-872. https://doi.org/10.1111/j.1540-6520.2011.00482.x

Covin, J. G., \& Slevin, D. P. (1986). The development and testing of an organizational-level entrepreneurship scale. Frontiers of entrepreneurship research, 1(3), 628-639.

Covin, J. G., \& Slevin, D. P. (1988). The influence of organization structure on the utility of an entrepreneurial top management style. Journal of Management Studies, 25(3), 217-234. https://doi.org/10.1111/j.1467-6486.1988.tb00033.x

Covin, J. G., \& Slevin, D. P. (1989). Strategic management of small firms in hostile and benign environments. Strategic Management Journal, 10(1), 75-87. https://doi.org/10.1002/smj.4250100107

Covin, J. G.; Slevin, D. P.; Schultz, R. L. (1994). Implementing Strategic Missions: Effective Strategic, structural, and Tactical Choices. Journal of Management Studies, 31(4), 481-503. https://doi.org/10.1111/j.1467-6486.1994.tb00627.x

De Massis, A., Kotlar, J., Wright, M., \& Kellermanns, F. W. (2017). Sector-based entrepreneurial capabilities and the promise of sector studies in entrepreneurship. Entrepreneurship Theory and Practice, 42(1), 3-23. https://doi.org/10.1177/1042258717740548

Drucker, P. F. (1985). Innovation and entrepreneurship. Harper \& Row.

EBRD. (2010). Agribusiness sector strategy. European Bank for Reconstruction and Development, EBRD. https://www.ebrd.com/downloads/policies/sector/agr_comm.pdf

El Alaoui, A., Shopovski, J., Kvirkvaia, M., Alam, N., \& Ofili, O. U. (2016). Obstacles to entrepreneurship in Albania, Georgia, Morocco, Nigeria, and Pakistan. European Scientific Journal, 12(34), 1-22. https://eujournal.org/index.php/esj/article/view/8533/8103

Ensign, P. C. (1998). Interrelationships and horizontal strategy to achieve synergy and competitive advantage in the diversified firm. Management Decision, 36(10), 657-668. https://www.deepdyve.com/lp/emerald-publishing/interrelationships-and-horizontal-strategyto-achieve-synergy-and-MLPHnqjyn7?key=emerald

Etkowitz, H., \& Leydersdorff, L. (1995). The Triple Helix - University-Industry-Government Relations: A Laboratory for Knowledge Based Economic Development. EASST Review, 14(1), 1419. https://ssrn.com/abstract=2480085

Etzkowitz, H. (2002). The triple helix of university - industry - government: implications for policy and evaluation. Stockholm: Sweedish Institute for Studies in Education and Research. http://www.sister.nu/pdf/wp_11.pdf

Fayolle, A. (2013). Forewords. In V. Ramadani, \& R. C. Schneider, Entrepreneurship in the Balkans: Diversity, Support and Prospects (pp. ix-xi). Verlag Berlin Heidelberg: Springer. DOI: $10.1007 / 978-3-642-36577-5$

Fitz-Koch, S., Nordqvist, M., Carter, S., \& Hunter, E. (2017). Entrepreneurship in the agricultural sector: A literature review and future research opportunities. Entrepreneurship Theory and Practice, 42(1), 129-166. https://doi.org/10.1177/1042258717732958 
Gecaj, M., Shahu, E. O., Imami, D., Skreli, E., \& Jambor, A. (2018). Analysing the impact of subsidies in the Albanian agriculture sector-A comparative approach. 162nd EAAE Seminar The evaluation of new CAP instruments: Lessons learned and the road ahead. Budapest: EAAE. DOI: 10.22004/ag.econ.271964

George, G., Wood, D. R., \& Khan, R. (2001). Networking Strategy of Boards: Implications for Small and Medium-Sized Enterprises. Entrepreneurship-and-Regional-Development, 13(3), 269-286. https://ink.library.smu.edu.sg/lkcsb_research/4637

Gerbing, D. W., \& Anderson, J. C. (1988). An updated paradigm for scale development incorporating unidimensionality and its assessment. Journal of Marketing Research, 25(2), 186-192. DOl: $10.2307 / 3172650$

Guerrero, M., \& Urbano, D. (2010). The development of an entrepreneurial university. The journal of technology transfer, 37(1), 43-74. https://doi.org/10.1007/s10961-010-9171-x

Guerrero, M., \& Urbano, D. (2016). The impact of Triple Helix agents on entrepreneurial innovations' performance: An inside look at enterprises located in an emerging markets. Technological Forecasting and Social Change, 294-309. doi:http://dx.doi.org/10.1016/j.techfore.2016.06.015

Gupta, A. K., \& Govindarajan, V. (1984). Business unit strategy, managerial characteristics, and business unit effectiveness at strategy implementation. Academy of Management Journal(27), 25-41. doi:10.2307/255955

Gupta, V., \& Gupta, A. (2015). The Concept of Entrepreneurial Orientation. Foundations and Trends® in Entrepreneurship, 11(2), 55-137. http://dx.doi.org/10.1561/0300000054

Hattie, J. (1985). Methodology review: Assessing unidimensionality of tests and items. Applied Psychological Measurement, 9(June), 139-164.

https://doi.org/10.1177/014662168500900204

Henson, S., \& Cranfield, J. (2009). Building the political case for agro-industries and agribusiness in developing countries. In C. A. Silva, D. Baker, A. W. Shephard, C. Jenane, \& S. Miranda-daCruz (Eds.), Agro-industries for development (pp. 10-45). CAB International \& FAO. Food and Agriculture Organization of the United States. DOI: 10.1079/9781845935764.0010

Hughes, M., \& Morgan, R. E. (2007). Deconstructing the relationship between entrepreneurial orientation and business performance at the embryonic stage of firm growth. Industrial Marketing Management, 36(5), 651-661. https://hdl.handle.net/2134/26377

Hult, G. T., Snow, C. C., \& Kandemir, D. (2003). The Role of Entrepreneurship in Building Cultural Competitiveness in Different Organizational Types. Journal of Management, 29(3), 401-426. doi:10.1016/S0149-2063(03)00017-5

lqbal, Z., \& Malik, M. (2019). Entrepreneurial orientation and engagement of Pakistani small and medium enterprises in sustainable development practices: Mediating role of knowledge management. Business Strategy \& Development, 192-203. https://doi.org/10.1002/bsd2.53

Jennings, P. D., Greenwood, R., Lounsbury, M. D., \& Suddaby, R. (2013). Institutions, entrepreneurs, and communities: A special issue on entrepreneurship. Journal of Business Venturing, 28(1), 1-9. https://doi.org/10.1016/j.jbusvent.2012.07.001

Kantur, D. (2016). Strategic entrepreneurship: mediating the entrepreneurial orientation - performance link. Management Decision, 54(1), 24-43. DOI: 10.1108/MD-11-2014-0660

Keh, H. T., Nguyen, M. T., \& Ng, P. H. (2007). The Effects of Entrepreneurial Orientation and Marketing Information on the Performance of SMEs. Journal of Business Venturing, 22(4), 592-611. doi:10.1016/j.jbusvent.2006.05.003 
Kelley, D., Bosma, N. S., \& Amoros, J. E. (2011). Global entrepreneurship monitor: 2010 global report. GEM. https://entreprenorskapsforum.se/wp-content/uploads/2011/02/GEM-2010-GlobalReport.pdf

Knight, G. A. (1997). Cross-cultural reliability and validity of a scale to measure firm entrepreneurial orientation. Journal of Business Venturing(12), 213-225. https://doi.org/10.1016/S08839026(96)00065-1

Kruja, A. D. (2013a). Entrepreneurship and knowledge-based economies. Revista Românească pentru Educaţie Multidimensională, 5(1), 7-17. http://revistaromaneasca.ro/?p=838

Kruja, A. D. (2013b). The contribution of SMEs to the economic growth (Case of Albania). EuroEconomica, 32(1), 55-67. http://journals.univdanubius.ro/index.php/euroeconomica/article/view/1622/1533

Kruja, A. D. (2019). Synergic individual entrepreneurial orientation of university students: A new measurement model. In S. R. Nair, \& J. M. Saiz-Alvarez (Eds.), Handbook of Research on Ethics, Entrepreneurship, and Governance in Higher Education (pp. 371-397). IGI Global. DOI: 10.4018/978-1-5225-5837-8.ch017

Kume, A., Kume, V., \& Shahini, B. (2013). Entrepreneurial characteristics amongst university students in Albania. European Scientific Journal, 9(16), 206-225.

https://eujournal.org/index.php/esj/article/view/1144

Lewrick, M., Omar, M., Raeside, R., \& Sailer, K. (2011). Education for entrepreneurship and innovation: 'Management capabilities for sustainable growth and success. World Journal of Entrepreneurship, Management and Sustainable Development, 6(1/2), 1-18. https://www.academia.edu/26703488/Education_for_entrepreneurship_and_innovation_Man agement_capabilities_for_sustainable_growth_and_success_

Leydesdorff, L. (2018). Synergy in Knowledge-Based Innovation Systems at National and Regional Levels: The Triple-Helix Model and the Fourth Industrial Revolution. Journal of Open Innovation: Technology, Market, and Complexity, 4(2), 2.

RePEc:gam:joitmc:v:4:y:2018:i:2:p:16-:d:146606

Leydesdorff, L., \& Meyer, M. (2006). Triple Helix indicators of knowledge-based innovation systems: Introduction to the special issue. Research Policy, 35(10), 1441-1449. https://www.leydesdorff.net/rp06th5/rp06th5.pdf

Leydesdorff, L., Etzkowitz, H., Ivanova, I., \& Meyer, M. (2017). The measurement of synergy in innovation systems: Redundancy generation in a triple helix of university-industrygovernment relations. Heidelberg: Springer. RePEc:sru:ssewps:2017-08

Li, Y. H., Huang, J. W., \& Tsai, M. T. (2009). Entrepreneurial Orientation and Firm Performance: The Role of Knowledge Creation Process. Industrial Marketing Management, 38(4), 440-449. https://doi.org/10.1016/j.indmarman.2008.02.004

Lumpkin, G. T., \& Dess, G. G. (1996). Clarifying the entrepreneurial orientation construct and linking it to performance. Academy of Management Review, 21(1), 135-172. DOI: 10.2307/258632

Lumpkin, G. T., \& Dess, G. G. (2001). Linking two dimensions of entrepreneurial orientation to firm performance: The moderating role of environment and industry life cycle. Journal of Business Venturing, 16(5), 429-451. http://www.sciencedirect.com/science/article/pii/S08839026(00)00048-3

Marshall, A. (1930). Principles of economics. London: Macmillan (first edition 1890). http://www.library.fa.ru/files/Marshall-Principles.pdf 
McClelland, D. C. (1961). The achieving society. NJ: Van Nostrand: Princeton. https://www.worldcat.org/title/achieving-society/oclc/230046

Mhlanga, N. (2010). Private sector agribusiness investment in sub-saharan africa. Food and Agriculture Organization of the United Nations (FAO). http://www.fao.org/3/k7443e/k7443e.pdf

Miller, D. (1983). The correlates of entrepreneurship in three types of firms. Management Science, 29(7), 770-791. https://doi.org/10.1287/mnsc.29.7.770

Miller, D. (2011). Miller (1983) revisited: A reflection on EO research and some suggestions for the future. Entrepreneurship Theory and Practice, 35(5), 873-894. https://doi.org/10.1111/j.1540$6520.2011 .00457 . x$

Miller, D., \& Friesen, P. H. (1982). Innovation in conservative and entrepreneurial firms: two models of strategic momentum. Strategic Management Journal(3), 1-25.

https://doi.org/10.1002/smj.4250030102

Montensen, P. S., \& Bloch, C. W. (2005). Oslo Manual-Guidelines for Collecting and Interpreting Innovation Data: Proposed Guidelines for Collecting and Interpreting Innovation Data. Organisation for Economic Cooporation and Development, OECD. http://www.oecd.org/science/inno/2367614.pdf

Nunnally, J. C. (1978). Psychometric Theory (2 ed.). New York: McGraw-Hill.

O`Brien, T., Nedelkoska, L., \& Frasheri, E. (2017). What is the Binding Constraint to Growth in Albania. Center for International Development at Harvard University. http://www.tinyurl.com/y5ld58ot

Pearce, J. W.; Carland, J. W. (1996). Intrapreneurship and Innovation in Manufacturing Firms: An Empirical Study of Performance Implications. Academy of Entrepreneurship Journal, 1(2), 87-96. DOI: 10.1142/S0218495801000092

Rauch, A., Wiklund, J., Lumpkin, G. T., \& Frese, M. (2009). Entrepreneurial orientation and business performance: An assessment of past research and suggestions for the future.

Entrepreneurship theory and practice, 33(3), 761-787. https://doi.org/10.1111/j.15406520.2009.00308.x

Rinkel, B. K., Cormier, C., Zheng, J. L., \& Saikat, M. S. (2016). Exploring Albania's Entrepreneurial Ecosystem. WPI. https://digitalcommons.wpi.edu/iqp-all/445

Schumpeter, J. (1911/34). The theory of economic development. Cambridge, Ma: Harvard University Press. https://www.hup.harvard.edu/catalog.php?isbn=9780674879904

Schwab, K. (2018). The global competitiveness report 2018-2019. World Economic Forum. http://www3.weforum.org/docs/GCR2018/05FullReport/TheGlobalCompetitivenessReport201 8.pdf

Shane, S., \& Venkataraman, S. (2000). The promise of entrepreneurship as a field of research. Academy of Management Review, 25(1), 217-226. https://www.jstor.org/stable/259271

Slater, S. F., \& Narver, J. C. (2000). The Positive Effect of a Market Orientation on Business Profitability: A BalancedReplication. Journal of Business Research, 48(1), 69-73. http://www.sciencedirect.com/science/article/pii/S0148-2963(98)00077-0

Thomas, A. S., \& Mueller, S. L. (2000). A case for comparative entrepreneurship: Assessing the relevance of culture. Journal of International Business Studies, 31(2), 287-302. https://www.jstor.org/stable/155638 
Urban, B. (2012). The effect of pro-entrepreneurship architecture on organizational outcomes. Journal of Business Economics and Management, 13(3), 518-545.

https://doi.org/10.3846/16111699.2011.620153

Volk, T. (2010). Agriculture in the Western Balkan Countries (Vol. 57). Halle (Saale): IAMO. https://www.iamo.de/fileadmin/documents/sr_vol57.pdf

Volk, T., Rednak, M., Erjavec, E., Rac, I., Zhllima, E., Gjeci, G., .. Stevovic, M. (2019). Agricultural policy developments and EU approximation process in the Western Balkan countries. Publication Office of the European Union. DOI:10.2760/583399

Wiklund, J., \& Shepherd, D. (2003). Knowledge-based resources, entrepreneurial orientation, and the performance of small and medium sized businesses. Strategic Management Journal, 13071314. https://doi.org/10.1002/smj.360

Wiklund, J., \& Shepherd, D. (2005). Entrepreneurial Orientation and Small Business Performance: A Configurational Approach. Journal of Business Venturing, 20(1), 71-91.

https://doi.org/10.1016/j.jbusvent.2004.01.001

Wiklund, J. (1999). The sustainability of the entrepreneurial orientation-performance relationship. Entrepreneurship Theory \& Practice, 24(1), 37-48.

https://doi.org/10.1177/104225879902400103

Xheneti, M., \& Smallbone, D. (2008). The role of public policy in entrepreneurship development in postsocialist countries: A comparison of Albania and Estonia. EBS Review(24), 23-36. http://www.ebs.ee/file.php?21947

Yiu, D. W., \& Lau, C. (2008). Corporate entrepreneurship as resource capital configuration in emerging market firms. Entrepreneurship Theory and Practice, 32(1), 37-57.

https://doi.org/10.1111/j.1540-6520.2007.00215.x

Zahra, S. A., \& Covin, J. G. (1995). Contextual infuences on the corporate entrepreneurship performance relationship: A longitudinal analysis. Journal of Business Venturing, 10(1), 4358. https://doi.org/10.1016/0883-9026(94)00004-E

Zahra, Shaker A. (1991). Predictors and financial outcomes of corporate entrepreneurship: An exploratory study. Journal of Business Venturing, 6(4), 259-285. https://doi.org/10.1016/0883-9026(91)90019-A

Zenelaj, B., \& Kruja, A. (2017). Entrepreneurship intention of Albanian students: an evidence from computer engineering and business informatics programs. Academic Conference on Economics, Management and Marketing. Prague: AC-EMM.

Ziegler, M., \& Hagemann, D. (2015). Testing the unidimensionality of items: Pitfalls and loopholes. European Journal of Psychological Assessment, 31(4), 231-237. https://doi.org/10.1027/1015-5759/a000309

The research paper has been reviewed. | Received: September 3, 2019; Revised: November 13, 2019; Accepted: December 5, 2019; Prepublished online: January 2, 2020; Published: March 31, 2020 


\section{Appendix}

Table A1 | Dimensions and statements used to measure EO

\begin{tabular}{|c|c|c|}
\hline Dimension & Coding & Statement \\
\hline \multirow{3}{*}{ Innovativeness } & 11 & $\begin{array}{c}\text { In general, top managers of my firm favor a strong emphasis on R\&D, } \\
\text { technological leadership, and innovations. }\end{array}$ \\
\hline & 12 & $\begin{array}{c}\text { My firm has marked many new lines of products and services in the } \\
\text { past } 5 \text { years. }\end{array}$ \\
\hline & 13 & $\begin{array}{c}\text { Changes in products or services of my firm have usually been quite } \\
\text { dramatic in the past } 5 \text { years. }\end{array}$ \\
\hline \multirow{3}{*}{ Proactiveness } & P1 & $\begin{array}{l}\text { In dealing with its competitors, my firm typically initiates actions which } \\
\text { competitors then respond to. }\end{array}$ \\
\hline & P2 & $\begin{array}{c}\text { In dealing with its competitors, my firm is very often the first business } \\
\text { to introduce new product/services, administrative techniques, } \\
\text { operating techniques, etc. }\end{array}$ \\
\hline & P3 & $\begin{array}{l}\text { In dealing with its competitors, my firm typically adopts a very } \\
\text { competitive "undo-the-competitors" posture. }\end{array}$ \\
\hline \multirow{3}{*}{ Risk-taking } & R1 & $\begin{array}{l}\text { In general, top managers of my firm have a strong proclivity for high- } \\
\text { risk projects (with chance of very high return). }\end{array}$ \\
\hline & $\mathrm{R} 2$ & $\begin{array}{l}\text { In general, top managers of my business organization believe that } \\
\text { owing to the nature of the environment, wide-ranging acts are } \\
\text { necessary to achieve the firm's objectives. }\end{array}$ \\
\hline & R3 & $\begin{array}{l}\text { When confronted with decision-making situations involving } \\
\text { uncertainty, my firm typically adopts a bold, aggressive posture to } \\
\text { maximize the probability of exploiting potential opportunities. }\end{array}$ \\
\hline \multirow{5}{*}{ Autonomy } & A1 & $\begin{array}{c}\text { My firm requires individuals or teams to rely on senior managers to } \\
\text { guide their work. }\end{array}$ \\
\hline & A2 & $\begin{array}{l}\text { In general, the top managers of my firm believe that the best results } \\
\text { occur when the CEO and top managers provide the primary impetus }\end{array}$ \\
\hline & & for pursuing business opportunities. \\
\hline & A3 & $\begin{array}{l}\text { In my firm individuals and/or teams pursuing business opportunities } \\
\text { are expected to obtain approval from their supervisor(s) before making } \\
\text { decisions. }\end{array}$ \\
\hline & A4 & $\begin{array}{c}\text { In my firm the CEO and top management team play a major role in } \\
\text { identifying and selecting the entrepreneurial opportunities my firm } \\
\text { pursues. }\end{array}$ \\
\hline \multirow{2}{*}{$\begin{array}{l}\text { Competitive } \\
\text { aggressiveness }\end{array}$} & $\mathrm{CA}$ & My firm is very aggressive and intensively competitive. \\
\hline & C1 & My firm collaborates with universities or research institutions. \\
\hline \multirow{4}{*}{ Collaborativeness } & $\mathrm{C} 2$ & My firm collaborates with governmental institutions. \\
\hline & C4 & My firm collaborates with domestic businesses. \\
\hline & C5 & My firm collaborates with foreign businesses. \\
\hline & C6 & My firm collaborates with innovation NGOs. \\
\hline
\end{tabular}

Source: author 